\title{
Compromise eludes EC
}

\section{Munich}

To the dismay of consumers in Europe and developing countries, the European Communities (EC) have failed once again to gain Community-wide approval for food irradiation. Although irradiation has been approved in seven member states (most recently in Britain) and two others are in the process of approval, it is opposed by Germany and some others.

Although it is accepted that irradiation can prolong the shelf-life of foodstuffs by killing what bacteria they contain, the general application of the technique remains controversial. Some hold that irradiation may create potentially toxic chemicals, but governments such as that of Germany believe that irradiation is in any case unnecessary.

Italy, which held the EC presidency in the second half of 1990, had vowed to find a compromise, but the last EC Council meeting of the year in Rome failed to reach a conclusion.

An official of the Geneva-based World Health Organisation (WHO), Valery Abramov, says that WHO regards irradiation as a way of improving the food supplies of developing countries, and has therefore urged all countries to approve the procedure.

EC Commission officials in Brussels are also disappointed that no solution could be reached at Rome. "We see it as our role to protect the consumer", says one official. By allowing irradiation accompanied by proper labelling of irradiated foods, the EC could offer more variety to European consumers and "increase the trust for these products" in developing countries, which are often dependent on exporters for ensuring the quality of food products.

The negotiations appear to have broken down over the labelling of food products containing irradiated ingredients. Current EC regulations require labelling of ingredients that make up 25 per cent or more of the content of a foodstuff offered for sale. Most members would have accepted a similar threshold, but Italy and Spain insisted at Rome that irradiated ingredients should be labelled if they made up as little as "one-half of one per cent" of a product, says the official.

Germany and Luxembourg oppose all irradiation. The German Bundestag even voted in 1989 to try to persuade other EC member states to ban irradiation. But EC officials say it would probably be in Germany's interests to agree to common rules. Otherwise, Germany has no legal means of preventing the import of irradiated foods from other EC countries. It is widely believed that such imports have already begun.

Most of the present national laws would allow irradiation of any food product as long as it has been scientifically proved to be safe. France, for example, permits irradiation of potatoes, onions, garlic and shallots (to prevent sprouting), and spices, cereals, poultry and frogs' legs (to reduce bacterial contamination).

The European Commission is frustrated by the dispute, fearing that it may end up before the European Court of Justice. Precedent suggests that EC members would have to accept irradiated food products from abroad provided they are safe and properly labelled.

Reflecting popular sentiments, the European Parliament recommended in 1989 that irradiation should be banned in Europe except for herbs and spices. These have usually been preserved using ethylene oxide, which was recently banned because of its carcinogenic properties.

In Germany, where irradiation of food products for the domestic market is banned without special permission, nobody has dared to apply for such approval. Food irradiation plants in former East Germany were closed by the federal government immediately after reunification. But Germany continues to export irradiated foodstuffs.

Opponents of food irradiation, mostly independent lobby groups, have shifted their strategy over the past ten years. At first, they contended that radiation products linger in irradiated food that may ultimately be harmful. But even the hardliners, frustrated by a lack of scientific evidence for their claims, are falling back on the argument that irradiation is not necessary and that consumers should not be forced to accept it.

In an official statement in 1987, WHO declared that irradiation is "harmless" in doses less than 10,000 Gray*. Normally, much smaller doses are used: less than 1,000 Gray to prevent sprouting in onions and potatoes or to kill insects. Larger amounts are necessary to eliminate bacteria.

Just 500,000 tonnes of food are irradiated annually, including 400,000 tonnes of Soviet wheat, according to a Bundestag report. And even in the Netherlands, where irradiation has been approved for several classes of foodstuffs, the amount consumed is equivalent to "less than one meal per person a year" according to the EC official. Both the high cost of irradiation facilities and the lack of consumer acceptance have limited the use of the technique

Faced with stalemate, the Commission has been seeking a least-commondenominator regulatory solution. It tried to obtain a majority of member states to

*One Gray of radiation, which is equivalent to 100 rads. corresponds to one joule of energy absorbed by one kilogram of material. agree to the irradiation of just two or three foods, and then to build up the ECapproved list slowly as member states approved irradiation. But this approach foundered both on the length of the list and on the labelling issue.

The Commission may now be forced simply to agree to license the irradiation process and to devise acceptable labelling regulations. One difficulty is that Luxembourg, which holds the presidency of EC for the first half of this year, is unlikely to hurry a solution.

That is how the issue may end up in the courts. As soon as an EC-based producer of irradiated food tries to export to Germany, says Professor Johannes Diehl of the Federal Institute for Nutrition at Karlsruhe, there is the possibility of a lawsuit, a turn of events that Diehl considers "very probable". And, just as in the case where (then West) Germany tried to keep out certain imported beers, "Germany will lose another one", he predicts.

The position of developing countries may eventually be influenced by the decision, last May, of the US Food and Drug Administration (FDA) that irradiation may be used to kill salmonella and other harmful bacteria in domestic or imported poultry. Although the US poultry industry is believed to have made little use of the technique, the decision has been seen as a "green light" by many developing countries, according to Abramov of WHO. He expects Latin American countries that export poultry to benefit economically from the decision.

Steven Dickman AIDS RESEARCH

\section{Better late than never for minorities}

\section{Washington}

The US Public Health Service, which has come under fire for neglecting minorities in its AIDS research, has decided to make amends. As part of a new programme, federal health agencies will spend more than $\$ 6.2$ million this year to include more minorities and minority institutions in AIDS research. Over $\$ 2.4$ million of the total will go to three institutions Howard University, the University of Hawaii and the University of Puerto Rico - to pay for new equipment and personnel to bring them up to the research standards of an AIDS clinical trial centre. Much of the remaining funds will support the first clinical trials aimed specifically at minorities, who now make up some 44 per cent of all US AIDS cases.

Beyond increasing the representation of minorities in general clinical trials, the funding will support research on special risk factors for minority patients, including intravenous drug use.

Christopher Anderson 